\title{
SEPAL - a simple GIS-based tool to estimate sediment pathways in lowland catchments
}

\author{
J. Kiesel, B. Schmalz, and N. Fohrer \\ Department of Hydrology and Water Resources Management, Ecology Centre, Christian-Albrechts-University Kiel, Germany
}

Received: 15 January 2009 - Revised: 9 March 2009 - Accepted: 28 April 2009 - Published: 10 August 2009

\begin{abstract}
Even though soil loss in the lowlands imposes not as much a restriction on land use and agricultural productivity as in erosion affected mountainous areas, the input of fine sediment into the rivers and streams is a concern due to water quality issues and substrate siltation. Drains, river banks and agricultural fields are the three main sources of fine sediment in lowland regions. For a successful implementation of measures to decrease sediment input a well-founded knowledge of the individual entry pathways is essential. To assess the importance of possible entry pathways, a GIS based methodology (SEPAL) has been established combining the ABAG, a river bank erosion formula and a regression approach to include the contributions of drains. SEPAL has been applied on a study catchment in Northern Germany. The results show that $15 \%$ of the sediment input into the river comes from agricultural drains, $71 \%$ from river banks and $14 \%$ from adjacent fields. A comparison of the results with field-mapping and -sampling shows that the approach is plausible. The calculated total annual sediment input is $616 \mathrm{t} \mathrm{yr}^{-1}$, while the measured suspended sediment load is $636 \mathrm{tyr}^{-1}$. It can be concluded that the methodology is suitable for estimating sediment entry pathways and annual sediment loads in lowland catchments as a base for modelling projects and further investigations. However, further work is necessary for gaining sound knowledge about uncertainties and especially about the processes forcing sediment input from drains.
\end{abstract}

\section{Introduction}

Although the emphasis of erosion studies is focused on regions with steep slopes, erosion processes in lowland catchments should not be neglected (Imeson and Ward, 1972).

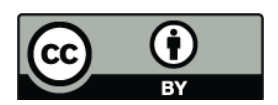

Correspondence to: J. Kiesel (jkiesel@hydrology.uni-kiel.de)
Fine sediment input into waterways has a decisive influence on water quality (Davies-Colley et al., 1992; Ryan, 1991), aquatic life-forms (Berry et al., 2003) and their habitat (Wood and Armitage, 1999), as well as anthropogenic usage like ship traffic and artificial water structures as harbors (Stevens and Ekermo, 2003). Especially in lowland regions, the siltation process of sediment can lead to necessary but harmful measures for the environment like dredging and mud extraction activities (Licursi and Gómez, 2009). Collins and Walling (2004) point out that, though it is difficult to acquire information about sediment entry pathways, it is important to understand sediment sources for deriving management plans and to prevent environmental problems. The main sediment entry pathways in lowlands are the input from agricultural drains, bank erosion and field erosion (Russel et al., 2001; Kronvang et al., 1997; Walling et al., 2002). Different criteria influence sediment input from these three sources: The sediment contribution from drains is highly variable and rarely researched. It seems to be governed by factors like soil type, groundwater levels, soil moisture, drainage depth and age, land use, irrigation (Walling et al., 2002; Stone and Krishnappan, 2002) as well as the size of the drained area (Smith et al., 2005). While Kronvang et al. (1997) and Stone and Krishnappan (2002) found sediment losses from drains of 20 to $130 \mathrm{~kg} \mathrm{ha}^{-1} \mathrm{yr}^{-1}$, Ulèn and Persson (1999) and Chapman et al. (2005) investigated drains under loamy and clayey soils with a high susceptibility to form macropores and measured extremely high values of up to 230 and up to $1000 \mathrm{~kg} \mathrm{ha}^{-1} \mathrm{yr}^{-1}$, respectively. River bank erosion depends on water flow characteristics like depth and velocity, freezing and thawing processes, the soil type, soil density and moisture, vessel traffic, cattle treading, as well as stream properties like curvature, cross-sectional shape and plant cover (Hooke, 1979; Saynor et al., 2003; Laubel et al., 1999; Bradbury et al., 1995; Wynn et al., 2004). It is generally considered as the main entry pathway for sediments in lowlands (Laubel et al., 1999; Kronvang et al., 1997; Hasholt, 1988).

Published by Copernicus Publications on behalf of the European Geosciences Union. 
Table 1. Input parameters for SEPAL, (D)rain-, (B)ank-, and (F)ield pathway.

\begin{tabular}{lllll}
\hline \multicolumn{1}{c}{ Parameter } & & Value & Unit & Reference \\
\hline Percentage of drained area (D) & $A_{d}$ & 38 & $\%$ & Fohrer et al., 2007 \\
Soil erosion factor (B) & $K$ & $0.061-0.143$ & - & Williams et al., 1995 \\
Adjacent land use value (B) & $A_{g f}$ & $1-16$ & - & Dickinson et al., 1989 \\
Soil Bulk density (B) & $B D$ & $0.60-1.65$ & $\mathrm{t} \mathrm{m}^{-3}$ & AD-HOC-AG, 2005 \\
Bank erosion height (B) & $h$ & 1 & $\mathrm{~m}$ & Field inspection \\
Critical water depth (B) & $h_{c}$ & 0.6 & $\mathrm{~m}$ & Zacharias, 2007 \\
Vicinity threshold (F) & $V_{S}$ & 100 & $\mathrm{~m}$ & Field inspection \\
Mean precipitation (F) & $N_{J}$ & 893 & $\mathrm{~mm}$ & DWD, 2007 \\
Soil erosion factor (F) & $K$ & $0.061-0.143$ & - & Williams et al., 1995 \\
Management factors (F) & $C ; P$ & $0.01-0.1 ; 0.5$ & - & Schwertmann et al., 1987 \\
\hline
\end{tabular}

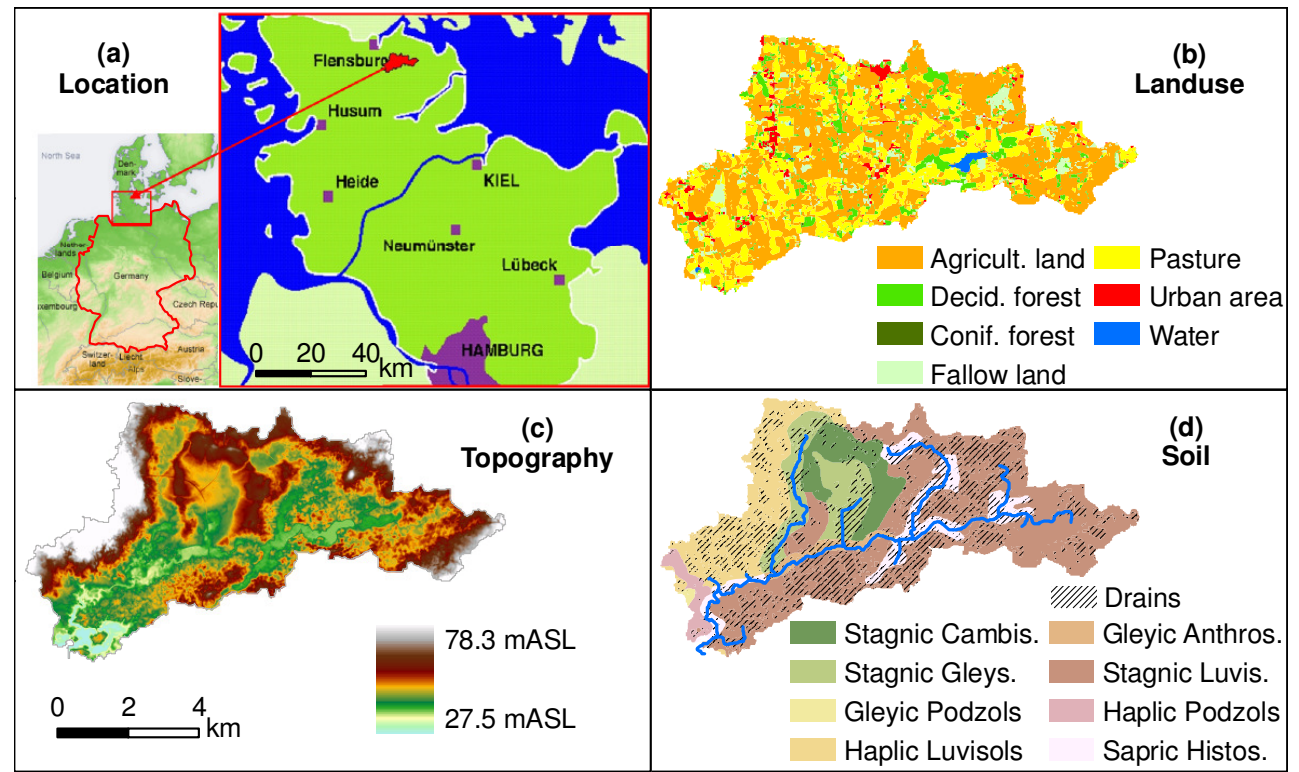

Fig. 1. (a) Location of the Kielstau catchment in Germany (Jose, 2006; LVA); (b) land use (DLR, 1995); (c) topography depicted on the $5 \mathrm{~m}$ DEM (LVA); (d) the river network (DAV-WBV/LAND S.-H., 2006), the soil (BGR, 1993) with drained areas (Fohrer et al., 2007).

For the fields, besides the influence of soil type, precipitation, topography and land management also drainage, hedgerow density and small scale field patterns due to anthropogenic influence (Hassenpflug, 1971) affect this entry pathway in lowlands.

The above-named processes of field and bank erosion are successfully implemented in a number of modelling concepts (Merritt et al., 2003; Bärlund et al., 2006; Tate, 2006). However, no modelling approach has so far been established for depicting sediment input from drains. Guidelines for estimating sediment budgets mostly cover only field and river bank erosion (Reid and Dunne, 1996). Though Walling (2005) stresses the importance of drain systems on the sediment source and delivery pathway, assessing the input quantities is rarely carried out because measurements on the catchment scale are tedious and cost intensive. Since neglecting one pathway would lead to a biased model calibration, it is necessary to incorporate all potential sediment pathways into modelling and planning processes for the successful development and assessment of management measures. It is the scope of this study to derive a pragmatic desktop approach for estimating the long-term share of the three sediment entry pathways in lowlands by combining remote sensing and structural river data with knowledge from comparable research studies. To validate the model estimations calculated results are compared with field measurements. The field approach consists of erosion mapping, erosion pin readings and suspended sediment sampling. 


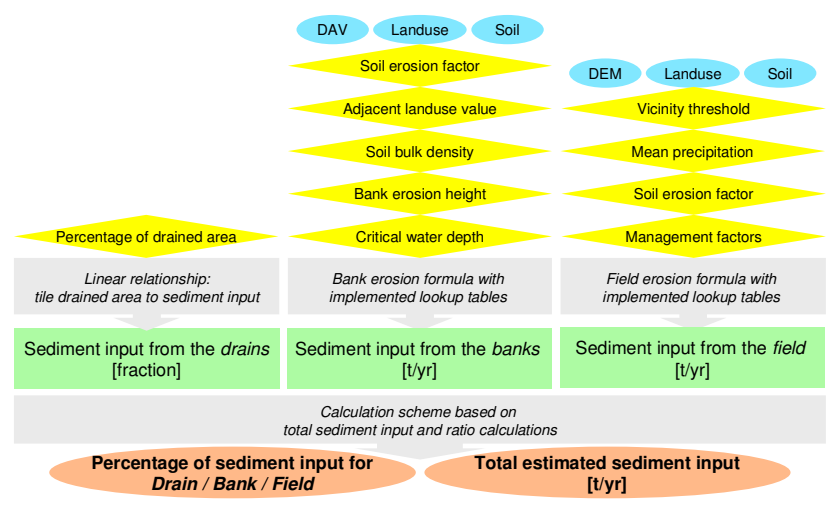

Fig. 2. GIS maps (blue ovals), user input parameters (yellow diamonds), calculation processes (gray rectangles), intermediate values (green rectangles) and output (red ovals) necessary for calculating the sediment input from the three pathways (drains left, banks middle and fields right).

\section{Investigation area}

The study area in which the developed methodology has been tested is located in the Northern German lowlands (Fig. 1a). The land use of the $50 \mathrm{~km}^{2}$ Kielstau catchment is dominated by arable land and pasture (Fig. 1b). The mean annual precipitation and temperature are $893 \mathrm{~mm}$ and $8.3^{\circ} \mathrm{C}$ respectively (DWD, 2007). The relatively flat topography (Fig. 1c) with rolling hills and numerous depressions in the catchment is typical for the north eastern Schleswig-Holstein landscape (Lorentzen, 1938) and leads to a low surface runoff fraction and low hydraulic gradients. Predominant soil types are haplic luvisols in the eastern and stagnic luvisols in the western part while sapric histosols are occurring along the stream and its tributaries. Extensive drainage measures have been implemented during the reallocation of land, mainly from the 1950s to the late 1970s (MELF, 1980). The drain location has been estimated by Fohrer et al. (2007) (Fig. 1d). Due to the typical lowland processes occurring in the Kielstau catchment it is a suitable area for applying and testing the developed tool for assessing sediment entry pathways.

\section{Methods}

\subsection{Desktop tool SEPAL}

The GIS-based SEPAL (Sediment Entry Pathway Assessment in Lowlands) approach has been implemented in an ArcGIS9.2 script. The script consists of one calculation process for each sediment entry pathway. The presented equations can not be used to quantify the sediment input for short time periods or single events. Only long term yearly average estimations are possible. The simplified flowchart in Fig. 2 shows the required GIS maps, the user input parameters, the calculation tasks, intermediate data and the output. The val- ues for the necessary input parameters for applying SEPAL in the Kielstau are explained in Table 1. The results of the three processes are combined in a simple scheme that calculates the percentage of sediment input for each pathway.

The sediment input from the river banks is calculated with the bank retreat equation by Dickinson et al. (1989). Dickinson's formula originally yields the absolute bank retreat only and is thus modified to Eq. (1) by taking the actual river section length and erosive bank height into consideration to gain the total sediment input from the banks:

$Y_{b}=\sum_{i}\left[\left(2 \times 10^{-10}\left(K_{i}^{2.5} \times A_{g f_{i}}^{7.2}\right)+1.75^{\frac{h m_{i}}{2 \times h_{c}}}\right) \times B D_{i} \times L_{i} \times h\right]$

where $Y_{b}\left[\mathrm{t} \mathrm{yr}^{-1}\right]$ is the sediment input from the two river banks for the whole river length. $i[-]$ is the river section number adopted from the river structure mapping (DAV) for sections susceptible to erosion (DAV-WBV/LAND S.-H., 2006). In the DAV database, rivers are partitioned in sections with equal morphological properties. The average segment length is $130 \mathrm{~m}$ for the study stream and contains information on substrate, incision depth and cross section geometry. $K[-]$ is the soil erosion factor for each soil type. $A_{g f}[-]$ is a corresponding value for the adjacent land use which can be taken from a look up table in Dickinson et al. (1989). $h_{m}[\mathrm{~m}]$ is the maximum possible water depth, taken from the DAV database. $h_{c}[\mathrm{~m}]$ is the critical water depth at which bed load transport begins. $B D\left[\mathrm{t} \mathrm{m}^{-3}\right]$ is the bulk density of the soil, $L[\mathrm{~m}]$ is the river section length from the DAV and $h[\mathrm{~m}]$ the bank height up to which erosion can occur.

Because processes and factors governing and affecting sediment input from drains are not yet researched, only an empirical regression approach could be implemented. Equation (2) is used to derive the sediment input share from drains:

$F_{d}=\frac{I_{d m}}{100} \times A_{d}$

where $F_{d}[\%]$ is the estimated percentage of sediment input from the drains. $I_{d m}$ [38.9\%] is the percentage of the sediment input from drains if the catchment would be $100 \%$ drained. This value is calculated from Table 2 with $[26.0 \%+59.0 \%+31.6 \%] / 3$ based on three studies carried out in catchments in Denmark and the United Kingdom with similar properties as the Kielstau catchment. $A_{d}[\%]$ is the percentage of the actual drained catchment area on the total catchment area, which is the necessary user input parameter for the investigated catchment.

Except for intensive rain events, the sediment input is expected to come mainly from riverbanks and drains. Imeson and Ward (1972) state, that the sediment input from fields in lowland catchments is minor because of the small fraction of surface runoff entering the streams directly. Hence, it can be assumed that sediment is entering the stream only from adjacent, sloping areas and according to DVWK (1996) mainly 
Table 2. Percentage of sediment input from drains based on percentage of drained catchment area, bold numbers are the linear extrapolation if the catchment would be $100 \%$ drained.

\begin{tabular}{lcccllc}
\hline Study and country & Time period & $\%$ drained area & $\%$ sediment input & Soil & Land use & ${\text { Precipitation }\left[\mathrm{mm} \mathrm{yr}^{-1} \text { ] }\right.}$ \\
\hline Kronvang et al., 1997; Denmark & $1993-1996$ & $50 \mathbf{1 0 0}$ & $13.0 \mathbf{2 6 . 0}$ & Moranic deposits & $90 \%$ farmed & 720 \\
Walling et al., 2002; UK & $1997-1999$ & $90 \mathbf{1 0 0}$ & $53.0 \mathbf{5 9 . 0}$ & Silty clay loams & Mixed agriculture & 660 \\
Walling et al., 2002; UK & $1998-1999$ & $90 \mathbf{1 0 0}$ & $28.5 \mathbf{3 1 . 6}$ & Clayey \& also permeable & Mixed agriculture & 660 \\
\hline
\end{tabular}

from agriculturally used fields during intensive rain events. Thus, the sediment input from the fields is estimated only for areas within a certain vicinity to the open stream channel. Equation (3) is based on the German revision of the Universal Soil Loss Equation (ABAG, Schwertmann et al., 1987; USLE, Wischmeier and Smith, 1978) and is implemented in the GIS script:

$Y_{f}=\sum_{c}\left[R \times K_{c} \times L_{c} \times S_{c} \times C_{c} \times P \times A_{c}\right]$

while $c$ lies within $V_{S}$ to the open stream channel

where $Y_{f}\left[\mathrm{tyr}^{-1}\right]$ is the sediment loss from the adjacent fields. $c$ is the grid cell. $R$ is the rainfall erosion factor based on the equation for Schleswig-Holstein (Sauerborn, 1994): $R=-21.08+0.0905 \times \mathrm{N}_{J}$ where $\mathrm{N}_{J}[\mathrm{~mm}]$ is the mean annual precipitation. $K$ is the soil erodibility factor for each soil type. $L$ is the slope length calculated from the Digital Elevation Model (DEM) according to Wischmeier and Smith (1978). $S$ is the slope steepness factor calculated from the DEM for slopes $<9 \%$ according to Feldwisch (1995) and for slopes $>9 \%$ according to Renard et al. (1997). $C$ is the covermanagement factor. $P$ is the support practice factor. $A$ [ha] is the area of the DEM grid cell. $V_{s}[\mathrm{~m}]$ is a proximity parameter for the GIS calculations which is based on the relief of the catchment. Therefore, field inspections might be useful to estimate the average overland distance that sediment can possibly be transported to the stream channel. Apart from the total accumulated sediment loss, the GIS implementation of the ABAG also allows the spatial regionalization of erosive grid cells in a map.

The results from Eqs. (1) (2) and (3) are used in Eqs. (4) and (5) to calculate the fractions of sediment input for all three pathways:

$$
\begin{aligned}
& F_{b}=\left(100-F_{d}\right) \times \frac{Y_{b}}{Y_{b}+Y_{f}} \\
& F_{f}=\left(100-F_{d}\right) \times \frac{Y_{f}}{Y_{b}+Y_{f}}
\end{aligned}
$$

where $F_{b}, F_{f}$ and $F_{d}[\%]$ are the estimated percentage of sediment input from the banks, fields and drains. $Y_{b}$ and $Y_{f}\left[\mathrm{tyr}^{-1}\right]$ are the sediment inputs from the banks and fields. Now, the average total estimated sediment input ( $Y_{\text {tot }}$ [ $\left.\mathrm{yr}^{-1}\right]$ ) can be calculated in Eq. (6):

$$
Y_{\mathrm{tot}}=\frac{Y_{b}+Y_{f}}{F_{b}+F_{f}} \times 100
$$

\subsection{Field measurements}

For testing the results of the SEPAL approach, field measurements were carried out: The bank retreat is quantified via erosion pins for three river sections that are marked in the structural river mapping database (DAV-WBV/Land S.H., 2006) as susceptible to erosion. Hooke (1978), Laubel et al. (1999) and Saynor et al. (2003) describe the general usage of erosion pins from which the methodology for this study has been derived. The used erosion pins are stainless steel rods with a diameter of $5 \mathrm{~mm}$ and a length of $0.5 \mathrm{~m}$. A representative river section of $300 \mathrm{~m}$ length has been chosen where 21 erosion pins have been placed in the banks at three different sites at low flow conditions on 7 July 2008. The pins are pushed in the banks and the distance from the tip of the pin to the river bank is immediately recorded for each pin. The time interval of erosion pin measurements to quantify the bank retreat generally ranges from certain storm events to years (Hooke et al., 1979). The distance measurements from the pin tip to the banks are carried out with a calliper and are conducted from each side of the pin (left, right, above and below) and the mean value is calculated. The distance from the pin tip to the bank was measured on 1 December 2008 in order to gain information about the bank retreat since 7 July 2008.

The field erosion is assessed by mapping campaigns according to DVWK (1996). First of all, a classification of river sections is obtained with topographic maps (1:25000 scale) and aerial photographs (1:5000 scale) in order to plan the mapping along the main channel of the Kielstau. The mapping took place on 22 April 2008 and 29 April 2008 where erosive patterns have been paced off and captured in sketches on a scale of 1:5000 and on digital photos. The gained information has been digitized in the GIS in order to compare mapped erosive fields with the calculated ABAG map.

As a continuous assessment, aggregated daily suspended sediment samples at the catchment outlet are taken since July 2007 with an automatic sampler and are used to calculate the sediment load of the Kielstau according to DVWK (1999): $1 \mathrm{~L}$-samples are taken and filtrated with a $65 \mu \mathrm{m}$ filter. The 
Table 3. Erosion pin readings expressed as the mean distance from pin tip to river bank; the calculated bank retreat for the 5 month period and the yearly average; all values in $[\mathrm{cm}]$

\begin{tabular}{lrrrrrrrrrrrrrr}
\hline Pin number & 2 & 3 & 4 & 5 & 6 & 7 & 8 & 9 & 16 & 17 & 18 & 19 & 20 & 21 \\
\hline Mean 7 Jul 2008 & 3.9 & 4.2 & 3.1 & 2.6 & 3.7 & 3.4 & 3.6 & 2.9 & 3.3 & 3.8 & 3.1 & 3.1 & 4.3 & 3.4 \\
distance 1 Dec 2008 & 5.9 & 7.8 & 3.3 & 2.7 & 4.1 & 3.7 & 4.1 & 3.4 & 3.9 & 4.1 & 3.2 & 3.4 & 4.3 & 3.1 \\
Bank retreat 5 mon & 2.1 & 3.6 & 0.2 & 0.1 & 0.4 & 0.3 & 0.4 & 0.5 & 0.6 & 0.3 & 0.0 & 0.3 & 0.0 & -0.3 \\
Yearly average & 7.4 & 12.8 & 0.6 & 0.3 & 1.4 & 1.2 & 1.6 & 1.6 & 2.0 & 1.2 & 0.0 & 0.9 & 0.1 & - \\
\hline
\end{tabular}

Pin not available on 1 December 2008: 1, 10, 11, 12, 13, 14, 15

Calculation example for pin number 2 to gain the yearly average:

$2.1 \mathrm{~cm} \times(147 \mathrm{~d} / 365 \mathrm{~d}) \times\left(0.43 \mathrm{~m}^{3} \mathrm{~s}^{-1} / 0.3 \mathrm{~m}^{3} \mathrm{~s}-1\right)=7.4 \mathrm{~cm}$

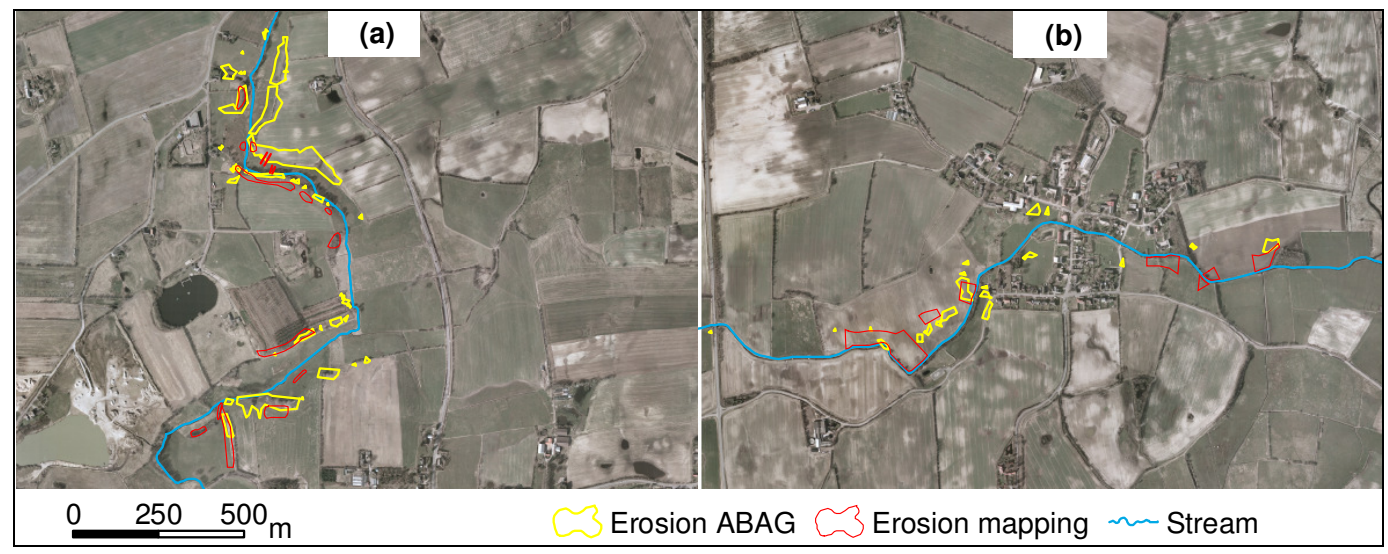

Fig. 3. Comparison of field erosion from ABAG calculation with field mapping on the downstream (a) and upstream erosive region (b) on aerial photographs (LVA).

filters are dried and weighed with a precision scale to obtain the mean daily sediment concentration $\left(\mathrm{mg} \mathrm{L}^{-1}\right)$. To gain the sediment load, the measured sediment concentration is multiplied with the daily mean discharge value $\left(\mathrm{m}^{3} \mathrm{~s}^{-1}\right)$ for the corresponding day.

\section{Results}

The SEPAL calculations led to a sediment input share of $15 \%$ from the drains, $71 \%$ from the river banks and $14 \%$ from the fields. The total sediment input, expressed as an annual mean value is estimated to be $616 \mathrm{t} \mathrm{yr}^{-1}$. The calculated bank retreat has a mean value of $2.9 \mathrm{~cm} \mathrm{yr}^{-1}$ for all erosive sections. This adds up to an average total sediment input by bank erosion of $437 \mathrm{t} \mathrm{yr}^{-1}$. The calculated soil loss from the fields ranges from 0 to $3.9 \mathrm{t} \mathrm{ha}^{-1} \mathrm{yr}^{-1}$. Taking the fields into consideration that are within $V_{s}=100 \mathrm{~m}$ vicinity to the streams, this leads to a mean total sediment input by field erosion of $88 \mathrm{tyr}^{-1}$. The yellow marked areas in Fig. 3 show the calculated erosive fields with an estimated sediment loss of $\geq 0.5 \mathrm{t} \mathrm{yr}^{-1}$ at the main channel. In total 112 locations have been depicted with a total area of 5.5 ha. The sediment input from all agricultural drains in the catchment is then calculated to $91 \mathrm{t} \mathrm{yr}^{-1}$.

The erosion pin readings for assessing the bank retreat are summarized in Table 3. Displayed are the measured mean values from the pin tip to the bank. The total bank retreat over the five month period is the difference of the mean values. The reading of pin 21 is not plausible, possible reasons can be either measuring errors or the pin has been pushed further into the bank by a possible collision with floating refuse. On the day of the measurements, seven pins have not been accessible due to high water levels. To compare the measurements with the SEPAL results, it is necessary to derive long-term average values from the measurements. The discharge regime during the measurement period is the main factor governing bank erosion and thus, the mean discharge over the five month period (147 days, $0.30 \mathrm{~m}^{3} \mathrm{~s}^{-1}$ ) and the long-term average (365 days, $0.43 \mathrm{~m}^{3} \mathrm{~s}^{-1}$ based on flow data from 1986 to 2009) is used for a linear extrapolation to gain yearly average values. The bank retreat ranges from 0 to $3.6 \mathrm{~cm}$ for the five month period and 0 to $12.8 \mathrm{~cm}$ for the long-term average with a mean value of $2.4 \mathrm{~cm} \mathrm{yr}^{-1}$ and a sediment input of $356 \mathrm{t} \mathrm{yr}^{-1}$ from bank erosion. 
The field mapping of erosive areas close to the stream is used for a comparison with the ABAG calculations. The fields found to be erosive are displayed in Fig. 3. In general the field erosion and the sediment input by surface runoff to the stream are assessed to be very low. In total 23 fields have been mapped as eroded, the largest being 1.3 ha, the mean area is 0.16 ha. The mapped total erosive area having potential to contribute sediment to the stream in case of intense rain events is 3.6 ha.

The daily suspended sediment samples can be used to calculate the total annual sediment load. The concentration ranges from 4.2 to $256 \mathrm{mg} \mathrm{L}^{-1}$ with a mean value of $22.3 \mathrm{mg} \mathrm{L}^{-1}$ over the 1.5 -year period. Multiplying the concentration with discharge data yields a load of $636 \mathrm{t} \mathrm{yr}^{-1}$.

\section{Conclusions}

The scope of this paper is the development of a pragmatic methodology to estimate the shares of the drain-, river bankand field sediment entry pathway in lowlands. The SEPAL approach has been tested in a rural $50 \mathrm{~km}^{2}$-catchment in Northern Germany. The results show that the bank erosion is predominant with $71 \%$, followed by the drains with $15 \%$ and fields with $14 \%$. No studies in other German lowland catchments are available. However, the results are assessed plausible when comparing them with five lowland catchments in Denmark. There, the bank sediment input shares are: $75 \%$ (Laubel et al., 1999), 77.5\% (Kronvang et al., 1997), 44\%, $82 \%$ and $56.7 \%$ (Hasholt, 1988), while the rest is caused by drain and field erosion input.

SEPAL is slightly overestimating the measured bank erosion as the formula calculated a $0.5 \mathrm{~cm} \mathrm{yr}^{-1}$ higher mean bank retreat and $84 \mathrm{t} \mathrm{yr}^{-1}$ higher soil loss from the banks as the erosion pin readings. Considering the simple approach of both measurement and calculation this is reasonable. Uncertainties can be due to the extrapolation of the five month pin measurements to gain the long-term average bank retreat value with the assumption that the measurement period is representative. The extrapolation takes the mean discharge into consideration, but other factors like peak flow intensity and distribution, freezing and thawing processes or plant cover are neglected. An improvement of the results is expected by extending the pin measurements to longer time periods. The discrepancy can also be due to the simple approach of the Dickinson formula which does not take the flow regime, bank slope and bank vegetation cover into consideration. However, Dickinson's formula appears to be a suitable compromise between exactness and data requirements for this task.

Hempel (1963) and Meyer (1996) stress, that the sediment input from the fields in the Kielstau region is very low. In fact, field erosion only occurs at two $1 \mathrm{~km}$-long river sections. The ABAG does not consider deposition and is thus susceptible to overestimating the actual sediment input into the streams. This is taken into account by restricting the appli- cation to adjacent river areas using the threshold value $\left(V_{S}\right)$. Overlaying the part of the ABAG map at the main stream channel with the field mapping (Fig. 3a and b) shows that generally, some mapped erosive fields are also depicted by the ABAG, while many fields that are estimated to be erosive have not been identified in the mapping campaign. Reasons for this can either be the field mapping at the end of April as some winter erosion events might not be visible anymore and also the coarse and generalized soil and land use map used for the ABAG calculations. Probably the main cause for this discrepancy is the low soil loss values from the ABAG in the range of $<1 \mathrm{tha}^{-1} \mathrm{yr}^{-1}$ which can be difficult to find in the field. The fact that the location and spatial extent of the fields show a relatively low agreement can be caused by the temporal difference between the data (early 1990s) and the mapping (2008). This can result in different field erosion locations due to the dynamic process of erosion and deposition. It can be concluded that the main erosive regions along the river have been identified sufficiently, but that the agreement on the smaller scale lacks exactness due to the mentioned objections.

Although the actual sediment input is expected to be higher than the suspended sediment transport due to possible deposition occurring in the stream, the calculated mean sediment input of $616 \mathrm{t} \mathrm{yr}^{-1}$ is within reasonable accordance with the load of $636 \mathrm{tyr}^{-1}$ calculated from the suspended sediment samples. Uncertainties and the most likely reason for underestimations are considered to be caused by the drain depiction, as the implemented drain sediment fractions from the literature are relatively low compared to sites with mainly clayey soils. Furthermore it is likely that local factors like the type and age of drain pipe, the existence and type of filter between drain pipe and soil, the number and location of sediment traps in the drain system as well as the common practice of farmers to purge the drain system in early spring influence this process.

SEPAL has proven to be easily and quickly to implement with only little data requirements. The comparison with other lowland studies and the measurements show that the approach is plausible. But as the obtained results have a considerable degree of uncertainty, the method should only be used as a first approach to gain an overview about possible predominant sediment pathways in lowlands. Such information can be valuable especially for integrated catchment modelling approaches that can depict field- and river bank- but not drain sediment input. The implemented regression equation for the drain input should and can easily be enhanced and extended if further data and research becomes available. In order to gain more reliable data especially for the drain sediment input, suggestions for further work are an intensification and temporal expansion of the measurement campaigns and collaborating with farmers concerning their drain maintenance so that dependencies of the sediment concentration can be derived and a physically based approach can be established. 
Acknowledgements. The authors thank the German Environmental Foundation (DBU) for the financial support of the first author.

Edited by: B. Schmalz, K. Bieger, and N. Fohrer

Reviewed by: two anonymous referees

\section{References}

AD-HOC-AG: Bodenkundliche Kartieranleitung, 5. Auflage, Hannover, 1-438, 2005.

Bärlund, I., Kirkkala, T., Malve, O., and Kämäri, J.: Assessing SWAT model performance in the evaluation of management actions for the implementation of the WFD in a Finnish catchment, Environ. Model. Softw., 22, 719-724, 2006.

Berry, W., Rubinstein, N., and Melzian, B.: The Biological effects of Suspended and Bedded Sediment (SABS) in Aquatic Systems: A Review, Internal Report, USEPA, 1-58, 2003.

BGR: Bundesanstalt für Geowissenschaften und Rohstoffe, Bodenübersichtskarte 1:200000 CC.1518 Flensburg, Hannover, 1999.

Bradbury, J., Cullen, P., Dixon, G., and Pemberton, M.: Monitoring and Management of Streambank Erosion and Natural Revegetation on the Lower Gordon River, Tasmanian Wilderness World Heritage Area, Australia, Environ. Manag., 19(2), 259272, 1995

Chapman, A. S., Foster, I. D. L., Lees, J. A., and Hodgkinson, R. A.: Sediment delivery from agricultural land to rivers via subsurface drainage, Hydrol. Proc., 19, 2875-2897, 2005.

Collins, A. L. and Walling, D. E.: Documenting catchment suspended sediment sources: problems, approaches and prospects, Prog. Phys. Geog., 28(2), 159-196, 2004.

Davies-Colley, R. J., Hickey, C. W., Quinn, J. M., and Ryan, P. A.: Effects of clay discharges on streams -1 . Optical properties and epilithon, Hydrobiologia, 248, 215-234, 1992.

DAV-WBV/LAND S.-H.: Digitales Anlagenverzeichnis S.-H., Wasser- und Bodenverbände und Land Schleswig-Holstein, 2006.

Dickinson, W. T., Rudra, R. P., and Wall, G. J.: Nomographs and software for field and bank erosion, J. Soil Water Conserv., 44(5), 596-600, 1989.

DLR: Landsat TM5-Scene, $25 \times 25 \mathrm{~m}$ resolution, German Aerospace Center, Köln, 1995.

DVWK: Bodenerosion durch Wasser - Kartieranleitung zur Erfassung aktueller Erosionsformen, Merkblätter 239/1996, 1996.

DVWK: Methoden zur Erkundung, Untersuchung und Bewertung von Sedimentablagerungen und Schwebstoffen in Gewässern, Schriften 128, 1999.

DWD: Weather and climate data from the German Weather Service, Offenbach, Station Flensburg 1957-2006, Offenbach, Germany, 2007.

Feldwisch, N.: Hangneigung und Bodenerosion, Boden und Landschaft, Schriftenreihe zur Bodenkunde, Landeskultur und Landschaftsökologie 3, JLU Gießen, 1995.

Fohrer, N., Schmalz, B., Tavares, F., and Golon, J.: Modelling the landscape water balance of mesoscale lowland catchments considering agricultural drainage systems (in German), Hydrol. Wasserbewirtsch., 51(3), 164-169, 2007.

Frede, G. and Dabbert, S.: Handbuch zum Gewässerschutz in der Landwirtschaft, ecomed Verlagsgesellschaft, Landberg, Ger- many, 1998.

Hasholt, B.: On identification of sources of sediment transport in small basins with special reference to particulate phosphorous, in: Sediment Budgets, edited by: Bordas, M. P. and Walling, D. E., Symposium Proceedings, Porto Alegre, Brazil, IAHS, 241$250,1988$.

Hassenpflug, W.: Studien zur rezenten Hangüberformung in der Knicklandschaft Schleswig-Holsteins, Forschungen zur dt. Landeskunde, 198, 1971.

Hempel, L.: Bodenerosion in Nordwestdeutschland Erläuterungen zu Karten von $\mathrm{SH}, \mathrm{HH}, \mathrm{NI}, \mathrm{HB} \& \mathrm{NW}$, Bundesamt für Landeskunde und Raumforschung, 144, 1963.

Hooke, J. M.: An analysis of the processes of river bank erosion, J. Hydrol., 42, 39-62, 1979.

Imeson, A. C. and Ward, R. C.: The output of a lowland catchment, J. Hydrol., 17, 145-159, 1972.

Jose: Relief Map of Europe, Wikimedia Commons, http:// commons.wikimedia.org, 2006.

Kronvang, B., Laubel, A., and Grant, R.: Suspended sediment and particulate phosphorous transport and delivery pathways in an arable catchment, Gelbaek Stream, Denmark, Hydrol. Proc., 11, 627-242, 1997.

Laubel, A., Svendsen, L. M., Kronvang, B., and Larsen, S. E.: Bank erosion in a Danish lowland stream system, Hydrobiologia, 410, 279-285, 1999.

Licursi, M. and Gómez, N.: Effects of dredging on benthic diatom assemblages in a lowland stream, J. Environ. Manage., 90, 973982, 2009.

Lorentzen, E.: Die Oberflächenformen der Landschaft Angeln und ihre Abhängigkeit vom Klimawechsel während der jüngsten Vereisung, Naturwiss. Ver. S.-H. 22(3), 387-449, 1938.

LVA: DEM for S.-H., map of S.-H. and aerial photograph, $5 \mathrm{~m}$ cell size, land survey office Kiel, 1992-2004.

MELF: 25 Jahre Flurbereinigung Schleswig-Holstein, Ministerium für Ernährung, Landwirtschaft und Forsten S.-H., 1980.

Merritt, W. S., Letcher, R. A., and Jakeman, A. J.: A review of erosion and sediment transport models, Environ. Model. Softw., 18, 761-799, 2003.

Meyer, M.: Erprobung und Anwendung von Methoden zur einzugsgebietsbezogenen Modellierung der Phosphatdynamik terrestrischer Ökosysteme, Diplomarbeit, available online: www. dilamo.de/martin/diplom.htm, (last access: December 2008), 1996.

Reid, L. M. and Dunne, T.: Rapid evaluation of Sediment Budgets, GeoEcology paperback, Catena Verlag, 1-164, 1996.

Renard, K. G., Foster, G. R., Weesies, G. A., McCool, D. K., and Yoder, D. C.: Predicting Soil Erosion by Water: A Guide to Conservation Planning With the Revised Universal Soil Loss Equation (RUSLE), USDA, Agriculture Handbook 703, 1997.

Russel, M. A., Walling, D. E., and Hodgkinson, R. A.: Suspended sediment sources in two small lowland agricultural catchments in the UK, J. Hydrol., 252, 1-24, 2001.

Ryan, P. A.: Environmental effects of sediment on New Zealand streams: a review, New Zealand, J. Mar. Freshw. Res., 25, $207-$ 221, 1991.

Sauerborn, P.: Die Erosivität der Niederschläge in Deutschland Ein Beitrag zur quantitativen Prognose der Bodenerosion durch Wasser in Mitteleuropa, Bonner Bodenkundliche Abhandlungen 13, 1994 (cited in Frede and Dabbert, 1998). 
Saynor, M. J., Erskine, W. D., and Evans, K. G.: Bank erosion in the Ngarradj catchment: Results of erosion pin measurements between 1998 and 2001, Supervising Scientist 176, Darwin, 2003.

Schwertmann, U., Vogl, W., and Kainz, M.: Bodenerosion durch Wasser, Vorhersage des Abtrages und Bewertung von Gegenmaßnahmen, Ulmer, 1987.

Smith, D. R., Haggard, B. E., Warnemuende, E. A., and Huang, C.: Sediment phosphorous dynamics for three tile fed drainage ditches in Northeast Indiana, Agric. Wat. Manage., 71, 19-32, 2005.

Stevens, R. L. and Ekermo, S.: Sedimentation and erosion in connection with ship traffic, Göteborg Harbour, Sweden, Environ. Geol. 43, 466-475, 2003.

Stone, M. and Krishnappan, B. G.: The effect of irrigation on tile sediment transport in a headwater stream, Water Res. 36, 34393448, 2002.

Tate, J. N.: Implementation and testing of a non-cohesive sediment library in the 2-D shallow water equations of adaptive hydraulics (ADH), 7th ICHE, Philadelphia, USA, 2006.

Ulèn, B. and Persson, K.: Field-scale phosphorus losses from a drained clay soil in Sweden, Hydrol. Proc., 13, 2801-2812, 1999.
Walling, D. E.: Tracing suspended sediment sources in catchments and river systems, Sci. Total Environ., 344, 159-184, 2005.

Walling, D. E., Russel, M. A., Hodgkinson, R. A., and Zhang, Y.: Establishing sediment budgets for two small lowland agricultural catchments in the UK, Catena, 47, 323-353, 2002.

Williams, J. R.: The EPIC Model, in: Computer Models of Watershed Hydrology, edited by: Singh, V. P., Chapter 25, 909-1000, 1995.

Wischmeier, W. H. and Smith, D. D.: Predicting Rainfall Erosion Losses, A guide to conservation planning, USDA Agricultural Handbook 537, 1978.

Wood, P. J. and Armitage, P. D.: Sediment deposition in a small lowland stream - management implications, Regulated Rivers, Res. Manage., 15(1-3), 199-210, 1999.

Wynn, T. M., Mostaghimi, S., and Elisabeth, F.: The Effects of Vegetation on Stream Bank Erosion, ASAE/CSAE Annual International Meeting, Ottawa, Canada, 2004.

Zacharias, P.: Bed load measurements in the Kielstau, Project course in environmental sciences, CAU Kiel, Dep. of Hydrology and Water Resources Management, unpublished, 2007. 